\title{
How the e-patient community helped save my life: an essay by Dave deBronkart
}

Dave deBronkart-otherwise known as e-Patient Dave-describes his four year odyssey from cancer diagnosis to international patient superstar. His journey shows the contribution that patients can make to the complexities of medicine

\section{Dave deBronkart policy adviser on patient engagement}

Nashua, New Hampshire, USA

In April 2009 I found myself on the front page of the Boston Globe. ${ }^{1}$ A mere cancer patient, I'd written a blog post about my medical record. ${ }^{2}$ The Globe's reaction—on page 1 -was my first glimpse of a big question: how can a patient say anything about medicine that's worthy of attention?

It was the start of an improbable odyssey, leading to speaking engagements at 200 meetings, a Salzburg global seminar on shared decision making, co-chairmanship of the Society for Participatory Medicine, testimony on government policy, events in many countries, and a TEDx talk ${ }^{3}$ that is in the top half of most viewed ever and has subtitles in 26 languages. Time and again I find myself wondering what people have heard that draws such interest; I wouldn't have been so bold as to predict it.

I think it is because, although I understand science-I love it, and I'm alive because of it-I also sense a substantial disconnect between what patients value and what medicine offers. And this raises the question: we all agree medicine should provide value for money, but who gets to say what value is?

\section{This is not anti-doctor}

I was saved by brilliant science and top notch clinicians. Diagnosed incidentally with stage IV, grade 4 metastatic renal cell carcinoma, I had bone metastases in my femur (which eventually fractured), ulna, and cranium; five metastases in my lungs; and muscle metastases in my thigh and tongue. Yet six months after diagnosis my treatment ended: I've not had a drop of anything since. A superb surgeon removed my kidney and adrenal gland; another repaired my femur (twice), and a skilled oncology team tended me through a difficult and dangerous treatment. Today I am well.

My gratitude goes out to every person who worked on development of the drug and the new protocol I received. Thank you to science, and to every clinician whose training and experience led them to be in the world class team at Beth Israel Deaconess Medical Center that saved my life. My family add their thanks.

\section{What is value and who provides it?}

What does my experience tell us about value? To understand a changing industry we must be clear about the elements that constitute value in medicine. Clearly, my team's achievements are valuable. Let's list some:

Awareness of status-I had no idea I was sick; I'd been tired and slowly losing weight, but at age 56 neither seemed a problem. I was unaware of my cancer until doctors spotted a shadow in my lung during a routine shoulder $x$ ray examination.

Accurate diagnosis-Radiology quickly suggested renal cell carcinoma, but my doctors didn't leap to a plan until a biopsy made it certain.

Current information on treatment options-I've since learnt that three out of four patients with metastatic renal cell cancer never hear of the treatment I got, high dosage interleukin-2 (IL-2). At the time it was the only drug that sometimes produced this result.

Surgical excellence-I was so sick that my nephrectomy had to be laparoscopic, which offers quicker recovery so the IL-2 could start. My surgeon says he almost had to fall back to open surgery. His skill was valuable. As was that of the orthopaedic surgeon: my leg works. I am repaired.

Clinical excellence - My unit treats 100 cases a year, which has given staff valuable practical knowledge. In the 1990s clinical trial used to approve IL-2, $4 \%$ of patients died from side effects. Today at my hospital only two of the last 600 patients have died. Furthermore, the response rate today is nearly double what it was in the 1990s; my oncologist, David 
McDermott, says the principal difference is that we've improved our ability to select likely responders.

I could go on, but the pattern is clear: there are many types of clinical value in the modern medical centre. Yet the institution isn't the only source of value. These system factors are valuable, too.

Access to the service-In my American case it was insurance coverage; while uninsured I'd postponed the appointment. But in any case if there's no access to a service, potential value goes unharvested. (Economically, the system is inefficient.)

Access to top notch information-In my case, this was first through access to a top medical centre, but as we'll see in a moment, that's not the only path.

Choice of provider-I chose to be treated at a great medical centre, even though it's an hour from home. To get there I have to drive past a dozen closer hospitals; only one offers IL-2 (and it has far fewer cases). Being allowed to get care there was clearly valuable to me, and it let my providers exercise the competence they'd developed.

\section{My being engaged and informed created value, too}

Consider the following, which are neither provider skills nor system issues, yet are clearly valuable.

Taking action to get checked-My cancer was discovered because I got a check-up, on general principle.

Planning ahead-Knowing that my leg might fracture, I asked what we should do if it happened. This led to a plan that worked: the fracture happened at $530 \mathrm{am}$, and I was in hospital by $10 \mathrm{am}$, in a methodical, non-dramatic fashion.

Being informed about choosing providers-Years earlier a relative, an intensive care nurse, had shared her sadness that some patients arrive at her tertiary centre too late to save.

That's what led me to connect to an academic centre long before my crisis. In a real sense, she saved my life by giving me that information, and I saved my life by acting on it.

And then consider these other factors that are outside the medical establishment. My online patient community has better information than most hospitals. ACOR.org is a network of simple plain-text listservs for patients with various cancers. One of its best is for renal cell carcinoma, and as soon as my diagnosis was confirmed, my primary physician (Danny Sands) said, "You're an online kind of guy, Dave-you might like to join this group." Within two hours of posting my first message, I got facts and practical advice that to this day don't exist in any journal article or establishment website.

As a responsible engaged patient, I constantly check with my clinicians. Dr McDermott has verified that the information is accurate. If peer review is the only true path to reliability, how could a patient community have better facts?

Some medical websites I consulted said $7 \%$ of IL-2 patients respond; the clinical trial, published in the National

Comprehensive Cancer Database, ${ }^{4}$ said $14 \%$ respond and $4 \%$ die. ACOR told me response had risen to $15 \%$; my hospital said it was up to $20 \%$, with only rare deaths. That's a massive difference compared with the official "facts." How can this be? I reported the $20 \%$ response rate to ACOR. The community's knowledge was immediately updated. It reminds me of the 2006 war between Encyclopaedia Britannica and Wikipedia. Both were found to have similar error rates ${ }^{5}$ — but Wikipedia's were fixed within days.

\section{ACOR's practical information may have saved my life}

As a responsible engaged patient, knowing that IL-2's side effects might kill me, I sought to prepare myself. First I sought authoritative sources; there I found dry facts: "Side effects are often severe and rarely fatal, and include ..." I thought, "What am I supposed to do with that?" and turned to my peers on ACOR. I asked, "You who've done this-what was it like? What do I need to know?" From them I received 17 firsthand stories - a wide range of experiences. I felt prepared-and today Dr McDermott says, "You were really sick. I don't know if you could have tolerated enough medicine if you hadn't been so well prepared." In this case valuable — as in potentially lifesaving - information came from outside the establishment.

\section{A new view of value}

To understand these anecdotes we need to understand what value is. That question is at the core of what Christensen dubbed disruptive innovation ${ }^{6}$; more recently, and more aptly, cardiologist Eric Topol has described it as "creative destruction," ${ }^{7}$ in which previously bundled elements of value become unbundled, making new things possible. If you're blind to this, it hurts when it hits.

It happened to me in the 1980 s, when my industry fell apart. I worked in typesetting, and along came the Mac. "Hello," said the first ads. Its first seminal application was desktop publishing, which enabled the great unwashed to use fonts, one of the core assets in the typesetting bundle. Another was the ability to lay out pages, which had previously required cut and paste or immensely expensive systems. Another was software to count character widths and hyphenate words at the end of a line- - not to mention more complex tasks, such as composing complex tables to display data more clearly. Last was the LaserWriter's ability to print complete pages. Everything about desktop publishing was far lower quality than what we in the trade offered, but the people with the need-the ultimate

stakeholders - could decide for themselves what was important to them. What they valued.

Today all those publishing capabilities exist, to varying degrees, in Microsoft Word and your home printer. And you probably have fonts in your phone. We who believed our expertise was the only source of value got a rude awakening.

I'd never say that medicine is like typesetting, but there are parallels that help us understand change as industries digitise. And, in particular, truths that can help us answer "What's going on here?" in the stories above.

To understand what's happening in medicine and more accurately see the future, we need to articulate what those particles of value are-so we can anticipate their "creative destruction," so we can avoid being blind to genuine value when it arises outside our model of thinking, so we can be effective in designing new solutions.

\section{"Doc Tom" saw it coming}

As I noted two years ago on the $B M J$ blog, ${ }^{8}$ I'm a disciple of Dr Tom Ferguson, a leader of patients as informed, engaged partners. He was a visionary when he wrote these words 10 years ago: "The emerging world of the e-patient cannot be fully 
understood and appreciated in the context of pre-internet medical constructs." $"$

In another article he commented, "Online patient-helpers with a chronic disease can be valuable resources for other patients with the same condition ... Clinicians must keep up to date on a wide variety of medical conditions while seeing dozens of patients a day. Patient-helpers ... will typically know only about their one disease, but since they can devote a great deal of time to it, their knowledge within that single narrow niche can be impressive." 10

Writing with Gilles Frydman, founder of ACOR, Ferguson predicted that "the 21 st century will be the age of the net empowered medical end user and that the patient driven online support networks of today will evolve into more robust and capable medical guidance systems that will allow end users to direct and control an ever growing portion of their own medical care. Doctors who continue to believe that their patients are inherently incapable of navigating the plentiful health resources of the internet will find their net savvy patients leaving them for other doctors. By contrast, those wise and caring doctors who realise that we may have just as much to learn from our patients as they have from us should do very well indeed."

Ferguson saw the future of internet enabled patient connections. At a deeper level, though, he saw the value patients were finding, creating, and even defining, on their own.

The baby boomer surge is forcing society to face decisions about costs-and particularly what is valuable. It's senseless for clinicians and governments to bear these choices alone; a sad effect of needless paternalism is that it places a false burden on responsible people. In other industries value is defined by the ultimate stakeholder - the one who benefits, or not, from the service. We should do the same in medicine.

We hear that if given the chance, patients will spend the earth—but the evidence says otherwise. ${ }^{11}$

\section{Saved by value, from clinicians and peers}

I close by reinforcing how grateful I am for excellence in medicine - and for the additional value I received from peers.
Two years after my treatment I had the deeply moving experience of walking my daughter Lindsey down the aisle at her wedding. And last Christmas she gave me a jigsaw puzzle, whose first solved portion said, "I can't wait to meet you!" It was an ultrasound: I have lived to see the birth of my first grandchild, this July. If that's not value, I don't know what is. The value delivered by skilled clinicians is still there, but now we can see that it's no longer the only source-and sometimes it's not even the best. According to patients. And even according to my oncologist.

Please, let patients help improve healthcare. Let patients help steer our decisions, strategic and practical. Let patients help define what value in medicine is.

Competing interests: I have read and understood the BMJ Group policy on declaration of interests and have no relevant interests to declare.

Provenance and peer review: Commissioned; not externally peer reviewed.

1 Wangsness L. Electronic health records raise doubts. Boston Globe 2009 Apr 13. www. boston.com/news/nation/washington/articles/2009/04/13/electronic_health_records_raise_ doubt.

2 e-Patient Dave. Imagine someone had been managing your data, and then you looked. 2009. http://e-patients.net/archives/2009/04/imagine-if-someone-had-been-managingyour-data-and-then-you-looked.html.

3 Meet e-Patient Dave. TEDx Maastricht: the future of health, 4 April 2011. http://on.TED. com/ePatientDave.

4 Fyfe G, Fisher RI, Rosenberg SA, Sznol SM, Parkinson DR, Louie AC. Results of treatment of 255 patients with metastatic renal cell carcinoma who received high-dose recombinant interleukin-2 therapy. J Clin Oncol 1995;13:688-96.

5 Giles J. Internet encyclopaedias go head to head. Nature 2005:438:900-1.

6 Christensen CM, Grossman JH, Hwang J. Innovator's prescription: a disruptive solution to health care. McGraw Hill, 2009.

7 Topol $\mathrm{E}$. The creative destruction of medicine: how the digital revolution will create better health care. Basic, 2012.

8 DeBronkart D. Back to the future: Tom Ferguson's "e patients" emerge in shared decision-making. 23 Dec 2010. http://blogs.bmj.com/bmj/2010/12/23/\%E2\%80\%9Cepatient-dave\%E2\% $\% 0 \% 9 \mathrm{D}$-debronkart-back-to-the-future-tom-ferguson $\%$ E2\% $\% 0 \% 99$ s\%E2\%80\%9Ce-patients\%E2\%80\%9D-emerge-in-shared-decision-making/.

9 Ferguson T, Frydman G. The first generation of e-patients. BMJ 2004;328:1148.

10 Ferguson T. Online patient-helpers and physicians working together: a new partnership for high quality health care. BMJ 2000;321:1129.

11 Oshima Lee E, Emanuel EJ. Shared decision making to improve care and reduce costs. N Engl J Med 2013;368:6-8.

Cite this as: BMJ 2013;346:f1990

(๑) BMJ Publishing Group Ltd 2013 